University of Nebraska - Lincoln

DigitalCommons@University of Nebraska - Lincoln

\title{
$5-2011$
}

\section{Rapid wetland expansion during European settlement and its implication for marsh survival under modern sediment delivery}

\section{rates}

Matthew L. Kirwan
A. Brad Murray
Jeffrey P. Donnelly
D. Reide Corbett

Follow this and additional works at: https://digitalcommons.unl.edu/usgsstaffpub

Part of the Geology Commons, Oceanography and Atmospheric Sciences and Meteorology Commons, Other Earth Sciences Commons, and the Other Environmental Sciences Commons

This Article is brought to you for free and open access by the US Geological Survey at DigitalCommons@University of Nebraska - Lincoln. It has been accepted for inclusion in USGS Staff -- Published Research by an authorized administrator of DigitalCommons@University of Nebraska - Lincoln. 


\title{
Rapid wetland expansion during European settlement and its implication for marsh survival under modern sediment delivery rates
}

\author{
Matthew L. Kirwan ${ }^{1 *}$, A. Brad Murray ${ }^{2}$, Jeffrey P. Donnelly ${ }^{3}$, and D. Reide Corbett ${ }^{4}$ \\ ${ }_{1}^{1}$ Patuxent Wildlife Research Center, U.S. Geological Survey, Charlottesville, Virginia 22904, USA \\ ${ }^{2}$ Nicholas School of the Environment, Duke University, Durham, North Carolina 27705, USA \\ ${ }^{3}$ Geology and Geophysics Department, Woods Hole Oceanographic Institution, Woods Hole, Massachusetts 02543, USA \\ ${ }^{4}$ Department of Geological Sciences, Institute for Coastal Science \& Policy, East Carolina University, Greenville, \\ North Carolina 27858, USA
}

\begin{abstract}
Fluctuations in sea-level rise rates are thought to dominate the formation and evolution of coastal wetlands. Here we demonstrate a contrasting scenario in which land-use-related changes in sediment delivery rates drive the formation of expansive marshland, and vegetation feedbacks maintain their morphology despite recent sediment supply reduction. Stratigraphic analysis and radiocarbon dating in the Plum Island Estuary (Massachusetts, United States) suggest that salt marshes expanded rapidly during the eighteenth and nineteenth centuries due to increased rates of sediment delivery following deforestation associated with European settlement. Numerical modeling coupled with the stratigraphic observations suggests that existing marshland could survive, but not form under the low suspended sediment concentrations observed in the estuary today. These results suggest that many of the expansive marshes that characterize the modern North American coast are metastable relicts of high nineteenth century sediment delivery rates, and that recent observations of degradation may represent a slow return to pre-settlement marsh extent. In contrast to ecosystem management practices in which restoring pre-anthropogenic conditions is seen as a way to increase ecosystem services, our results suggest that widespread efforts to restore valuable coastal wetlands actually prevent some systems from returning to a natural state.
\end{abstract}

\section{INTRODUCTION}

For more than 40 years, fluctuations in rates of sea-level rise have been thought to control the formation and behavior of coastal marshes. The elevation of a vegetated marsh platform quickly adjusts to the rate of sea-level rise (Redfield, 1965), rates of vertical accretion typically mimic rates of sea-level rise (Friedrichs and Perry, 2001), and many observations of marsh submergence and channel erosion today are attributed to a historical acceleration in the rate of sea-level rise (e.g., Friedrichs and Perry, 2001; Donnelly et al., 2004). The age of basal peat from modern high-elevation marshes indicates that initial marsh formation is also tied to the rate of sea-level rise (Redfield, 1965). Marshes became widespread along the North American coast during late Holocene sea-level deceleration 4 k.y. ago (Redfield, 1965; Rampino and Sanders, 1981). However, our analysis of the sedimentary record, combined with numerical modeling, suggests that sea-level rise rates may not be the dominant factor determining the evolution of some prominent marshes.

Following European settlement, most forestland along the North American coast was cleared for agriculture, which led to rapid and widespread soil erosion. In the southeastern United States, estimates of nineteenth century erosion ( 1 mm/yr; Trimble, 1977) exceed

*E-mail: mkirwan@usgs.gov. long-term estimates of piedmont denudation $(0.005 \mathrm{~mm} / \mathrm{yr}$; Pavich et al., 1985) by more than two orders of magnitude. Although not all the eroded sediment likely reached the coast (Trimble, 1977), sedimentation rates in Chesapeake Bay increased by as much as an order of magnitude (Colman and Bratton, 2003; Saenger et al., 2008). In the northeastern United States, significant land clearance began in the late seventeenth century, the acreage of farms peaked ca. 1850, and mineral sediment input into coastal Massachusetts ponds increased by approximately an order of magnitude (Hall et al., 2002; Parshall et al., 2003). The watershed of our study area $\left(585 \mathrm{~km}^{2}\right)$, the Plum Island Estuary in Massachusetts, was settled in the 1630s. By 1645, there was enough corn planted to justify grist mills on three of the major rivers (Rowley, Parker, Merrimack), and grist mills and sawmills were common by 1700 (Currier, 1902). Elsewhere in the region, paleoindicators of initial forest clearance were assigned an age of A.D. 1700 in Cape Cod (Parshall et al., 2003), and peak clearance was estimated in the adjacent Gulf of Maine at 1785 (Ward et al., 2008).

\section{METHODS}

To determine the stratigraphic history of the Plum Island Estuary, and its response to European land clearance, we collected 14 Vibracores from marshes surrounding the Rowley River in October 2006 (see the GSA Data Repository ${ }^{1}$ and Fig. DR1 therein). Based on sediment characteristics (e.g., the presence of in situ plant rhizome material and organic matter content $>10 \%-15 \%$ by mass), we identified the depth within each core that corresponded to the initial formation of salt marsh. We supplemented our estimates of peat thicknesses with those gleaned from 31 early core descriptions taken at Plum Island Estuary (McIntire and Morgan, 1963; McCormick, 1968) (Fig. DR2).

To determine the timing of marsh formation, we isolated individual rhizome pieces from near the base of the peat in each core to use for radiocarbon dating. We radiocarbon dated 23 samples by accelerator mass spectrometry and calibrated to calendar years at $2 \sigma$ (Table DR1). We supplemented our radiocarbon dates from near the peat base with additional dating techniques ${ }^{210} \mathrm{~Pb},{ }^{137} \mathrm{Cs}$, and heavy metal pollution horizon inferred from X-ray fluorescence scans of the cores) from samples collected near the surface of selected cores (Table DR2). These alternative dating approaches help discern between multiple calibrated age ranges and provide additional chronologic control, particularly in younger portions of the cores.

In an effort to estimate ages of marsh formation for cores without chronologic information, we compiled the results from all of our dating approaches into a single chronology to establish an age-depth relationship. Because young marshes had substantially higher accretion rates than older marshes (presumably due to their low elevation, the effect of land clearance, incomplete compaction, and/or recent trends in sealevel rise rates), we divided this chronology into two groups based on their age (Fig. DR3). We selected the appropriate age-depth relationship to use on undated cores based on their proximity to the nearest dated core. Such an approach assumes that thick peat represents relatively old marshes, and introduces error by assuming that portions of the marsh with similar peat thicknesses developed at similar times. However, our

${ }^{1}$ GSA Data Repository item 2011159, supplementary methods, Figures DR1-DR4, and Tables DR1 and DR2, is available online at www.geosociety .org/pubs/ft2011.htm, or on request from editing@ geosociety.org or Documents Secretary, GSA, P.O Box 9140, Boulder, CO 80301, USA 
goal was only to discern portions of the modern marsh that formed before and after settlement, rather than provide a precise date of formation.

\section{PATTERNS OF MARSH EXPANSION}

Our stratigraphic reconstruction of a portion of the Plum Island Estuary suggests that marshes here expanded from $\sim 6 \mathrm{~km}^{2}$ to $9 \mathrm{~km}^{2}$ in response to historical land-use change (Fig. 1A). Both our coring and earlier efforts (McIntire and Morgan, 1963; McCormick, 1968) indicate that before European settlement, this area consisted of an open water, subtidal bay surrounded by a fringe of marsh. Historical maps show that substantial marshland was already in place during the late eighteenth century (Des Barres, 1776),
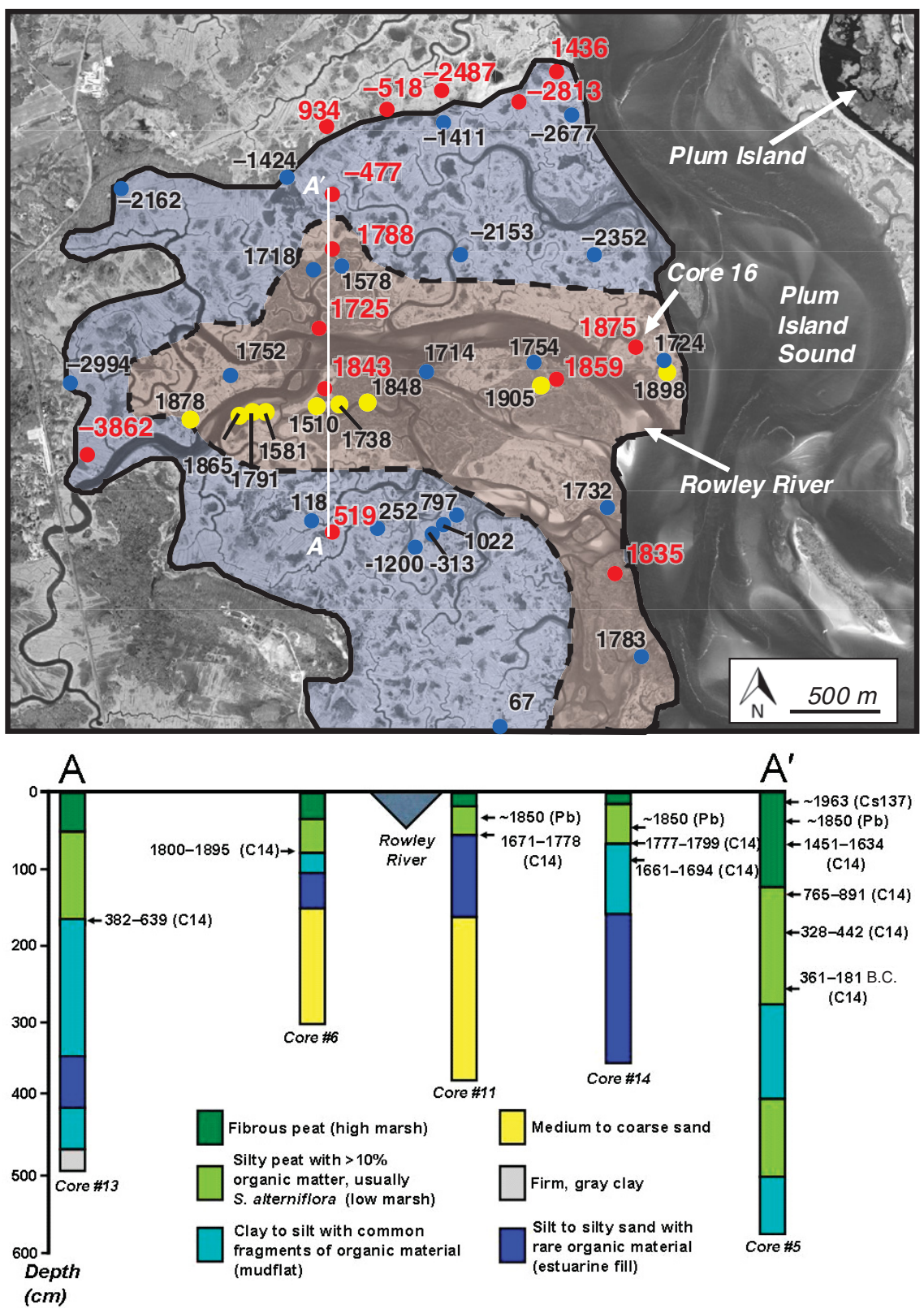

Figure 1. Top: Map of Plum Island Estuary (Massachusetts) study area showing extent of presettlement marsh (blue shading) and post-settlement marsh (pink shading). Dates of marsh formation on map represent calibrated radiocarbon dates from basal peat (red dots), or dates estimated from peat thickness reported by McIntire and Morgan (1963) (yellow dots) and McCormick (1968) (blue dots). Positive dates indicate years A.D., negative dates indicate years B.C. Bottom: Stratigraphic cross section perpendicular to Rowley River recording lateral progradation of marsh over unvegetated estuarine deposits. Green denotes sedimentary facies indicative of intertidal marshland (i.e., abundant organic matter), and blue denotes sedimentary facies indicative of unvegetated estuarine environments such as mudflats. Dated horizons are from onset of heavy metal pollution ( $\mathrm{Pb}$ ), peak in ${ }^{137} \mathrm{Cs}$ activity (Cs137), or calibrated radiocarbon dates (C14), and represent years A.D. unless otherwise indicated. although a large portion of the study area, covered by marsh today, was identified on an 1830 map as Shad Creek Bay (Anderson, 1830). Thick sequences of high marsh peat $(>5 \mathrm{~m})$ and radiocarbon dates from their base indicate that the fringing marsh has been in place for a few thousand years (Fig. 1A; Fig. DR2). However, our stratigraphic cross sections and detailed dating of basal peat reveal that the marsh prograded rapidly toward the modern-day Rowley River during the eighteenth and nineteenth centuries (Fig. 1B), converting subtidal and mudflat environments into what is now part of the most expansive marshland in New England.

Core 16 (Fig. 2) records the vertical response of a mudflat to an increase in sediment delivery rate associated with European settlement. In the lowest (oldest) section of the core, terrestrially derived element concentrations $(\mathrm{K}, \mathrm{Ti}, \mathrm{Fe})$ gradually decrease upward in the core, consistent with basin infilling and a slight decrease in inundation as mudflats build elevation relative to sea level (e.g., Zhou et al., 2004). At a core depth of $150 \mathrm{~cm}$, however, terrestrial element concentrations increase abruptly, despite no grossly discernable change in stratigraphy. Approximate age-depth relationships derived from the dating of multiple cores (see the Data Repository and Fig. DR3) suggest that the increase in terrestrial elements began in the early eighteenth century, which we interpret as a signal of landuse change. Organic-rich sediments containing Spartina alterniflora root material appear at a core depth of $79 \mathrm{~cm}$, indicating the initial development of a marsh. A radiocarbon date on an in situ rhizome at this boundary yields a calibrated $2 \sigma$ age range of A.D. 1802-1938 (mean $=1870)$. Terrestrial element concentrations decrease abruptly at this depth, consistent with a transition to a higher elevation surface that would be flooded for shorter periods of time.

Stratigraphic sequences that record progradation of marshes across a subtidal basin have traditionally been interpreted as the result of gradual basin infilling during periods of slow sea-level rise (Redfield, 1965; McCormick, 1968). However, our dated stratigraphy points to an abrupt period of marsh growth where rates of marsh expansion increased by about an order of magnitude following settlement $\left(\sim 1000 \mathrm{~m}^{2} \mathrm{yr}^{-1}\right.$ to $\sim 15000 \mathrm{~m}^{2} \mathrm{yr}^{-1}$ ). While river meandering and tidal channel erosion could remove older peat deposits and promote localized rapid accretion in marshes near the Rowley River, all of our cores were taken more than $10 \mathrm{~m}$ from channel edges, and recently formed marsh was observed more than $500 \mathrm{~m}$ from the modern Rowley River. These observations reinforce our interpretation that the expansive marshes in the Plum Island Estuary formed in response to historical land-use change rather than gradual infilling obscured by channel migration. 
Figure 2. Terrestrial element concentrations in Core 16. Gradual decrease in terrestrial element concentrations in lower half of core likely reflects reduced inundation associated with gradual basin infilling. Sharp increase in terrestrial element concentrations corresponds to land clearance and enhanced sediment delivery associated with European settlement. Our stratigraphy records transition from tidal flat to low marsh at depth of $79 \mathrm{~cm}$, dated

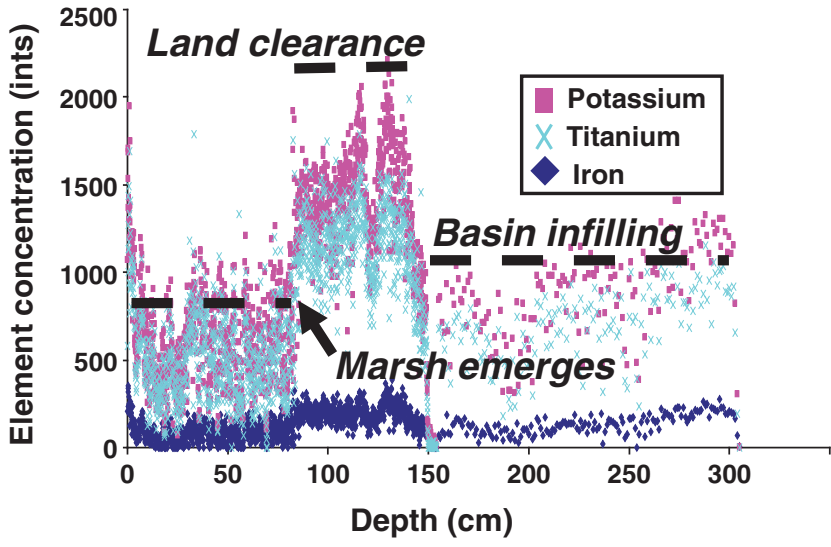

between A.D. 1802 and 1938 (79-301 cm, silt with common plant fragments; $79 \mathrm{~cm}$ to top, silty peat with abundant Spartina alterniflora material). Low terrestrial element concentrations following marsh formation likely reflect marsh's high elevation within tidal frame, and reduced sediment delivery associated with basin reforestation and dam construction.

Because our observations of large-scale marsh expansion occur even in an estuary with small tributaries that carry relatively little mineral sediment, it seems likely that historical land-use change drove the formation of expansive wetlands in other regions. For example, increased sediment delivery rates associated with agricultural development caused small subtidal deltas in the upper reaches of Chesapeake Bay tributaries to expand into intertidal freshwater marshland in the mid-nineteenth century (e.g., Gottschalk, 1945; Pasternack et al., 2001). Late nineteenth century deforestation caused mangroves to rapidly expand over historically stable tidal flats in the Firth of Thames, New Zealand (Swales and Bentley, 2008), and sedimentation from upland mining caused marshes to expand in San Francisco Bay, California (Gedan et al., 2009). Similarly, recent timber harvesting caused a small bay-head delta covered by salt marsh vegetation to form on a portion of the Newport River, North Carolina (Mattheus et al., 2009). Together, these examples suggest that historical changes in sediment delivery rates to the coast are strongly coupled to upstream land-use change. Though changes in sediment yields may be buffered by upstream storage (e.g., Trimble, 1977; Walter and Merritts, 2008), our work suggests that only some of the sediment related to agricultural deforestation was impounded.

\section{NUMERICAL MODELING AND DISCUSSION}

To further test our hypothesis that increases in sediment supply could drive wetland expansion, we conducted experiments with a previously developed numerical model (e.g., Kirwan and Murray, 2007), starting with a subtidal basin surrounded by a fringe of marsh occupying higher elevations (Fig. 3). In these experiments we maintain a constant rate of sea-level rise $(1 \mathrm{~mm} / \mathrm{yr}$, consistent with late Holocene rates; Donnelly et al., 2004), but adjust the concentration of suspended sediment present in tidal channels. At low suspended sediment concentrations $(\sim 0.001 \mathrm{~g} / \mathrm{L})$, both the fringe marsh and unvegetated subtidal surfaces accrete in equilibrium with the rate of sea-level rise, preserving a basin configuration dominated by open water (Fig. 3A). At high concentrations $(\sim 0.01-0.1 \mathrm{~g} / \mathrm{L})$, however, unvegetated surfaces accrete faster than the rate of sea-level rise and build to depths that can support vegetation. Since vegetation tends to reduce erosion and enhance accretion in the model (Kirwan and Murray, 2007), sparsely vegetated deep surfaces rapidly join the growing marsh platform (Fig. 3B). Our experiments suggest that a landscape defined by an expansive platform and intertwining channel network can replace a landscape dominated by open water in $<100 \mathrm{yr}$
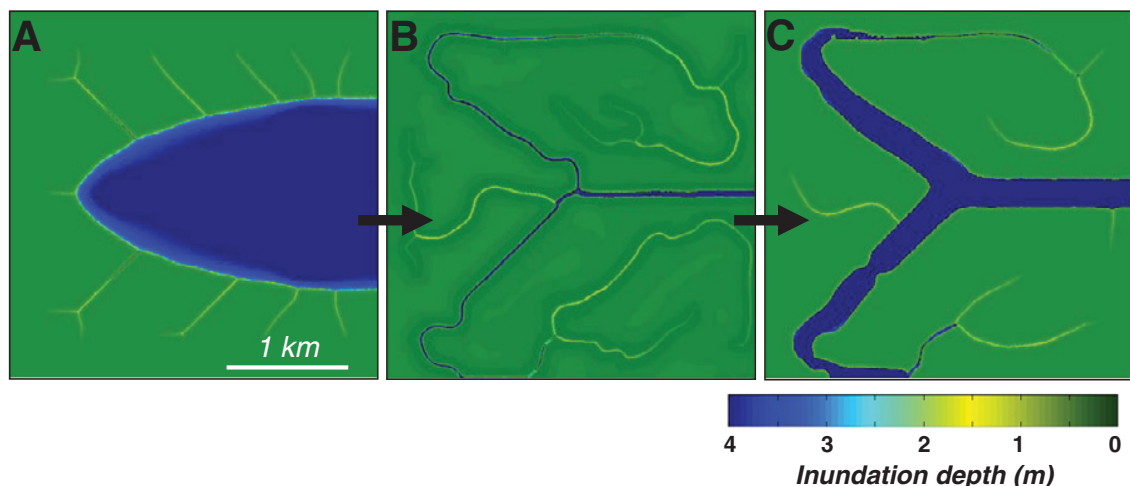

Figure 3. Modeled planform evolution of hypothetical estuary under constant rate of sealevel rise $(1 \mathrm{~mm} / \mathrm{yr})$. Initial condition was subtidal basin with narrow fringe of marsh occupying high-elevation perimeter. A: At low suspended sediment concentrations $(0.001 \mathrm{~g} / \mathrm{L})$, equilibrium basin configuration is dominated by unvegetated, subtidal surfaces. B: At high suspended sediment concentrations $(0.1 \mathrm{~g} / \mathrm{L})$, marshes expand across basin, replacing unvegetated surfaces as the dominant environment. C: At low suspended sediment concentrations (same as initial condition), expansive platform persists despite some platform deepening and channel widening. 
example, expansive marsh persists today under suspended sediment concentrations ( 0.001 g/L; Cavatorta et al., 2003; Hopkinson, 2007) that our model experiments predict are too low for marsh formation. Our observations of landuse-driven marsh expansion coupled with modeled resiliency to sediment supply reduction, therefore, suggest that expansive marshes persist today in a metastable equilibrium. If true, marshland that is lost today will not be replaced unless land-use patterns change drastically.

While our model experiments demonstrate resilience to large reductions in sediment supply, field observations of marsh degradation indicate that there are limits to the conditions under which ecogeomorphic feedbacks can allow an expansive marsh to persist. Sediment deficient marshes are submerging rapidly in the Chesapeake Bay and coastal Louisiana regions, for example, but are surviving in areas with high sediment input (Cahoon et al., 1995; Kearney et al., 2002). Similarly, marshes along the Yangtze River delta (China) that have grown seaward since the seventh century are now retreating landward due to sediment reduction associated with the Three Gorges Dam (Yang et al., 2005). Therefore, our observations of land-use-driven marsh expansion complement observations of sediment-driven degradation, and further emphasize the important role that sediment supply plays in marsh evolution.

If some expansive marshes are indeed a relict feature of historical land-use change, could widespread degradation observed today represent a slow return of marshes to their low sediment supply, pre-settlement extent? This transition would involve an enormous loss in ecosystem services, and raises an interesting paradox for managers and policy makers. Our results suggest that expensive wetland restoration may in some cases amount to an attempt to prevent coastal wetlands from returning to their natural state. While this approach maximizes ecosystem services that include storm protection, it strongly contrasts management objectives in other ecosystems (e.g., reintroducing prehistoric fire regimes to western North American forests).

\section{ACKNOWLEDGMENTS}

The National Science Foundation (grant EAR1617209) and the U.S. Geological Survey Global Change Research Program supported this work. We thank Steve Eberbach, Jeff Kirwan, Jessica Kirwan, Ryan Littlewood, and Nick Magliocca for their assistance in the field and lab.

\section{REFERENCES CITED}

Anderson, P., 1830, Map of Rowley: Boston, Pendelton's Lithography.

Cahoon, D.R., Reed, D.J., and Day, J.W., 1995, Estimating shallow subsidence in microtidal salt marshes of the southeastern United States: Kaye and Barghoorn revisited: Marine Geology, v. 128, p. 1-9, doi: 10.1016/0025-3227(95) 00087-F.
Cavatorta, J.R., Johnston, M., Hopkinson, C., and Valentine, V., 2003, Patterns of sedimentation in a salt marsh-dominated estuary: Biological Bulletin, v. 205, p. 239-241, doi: 10.2307/1543274.

Colman, S.M., and Bratton, J.F., 2003, Anthropogenically induced changes in sediment and biogenic silica fluxes in Chesapeake Bay: Geology, v. 31, p. 71-74, doi: 10.1130/0091-7613 (2003)031<0071:AICISA>2.0.CO;2.

Currier, J.J., 1902, History of Newbury, Mass. 16351902: Boston, Massachusetts, Damrell \& Upham, 755 p.

Des Barres, J.F.W., 1776, Ipswich Bay and Cape Ann, in The Atlantic Neptune: London, J.F.W. des Barres, 2 sheets.

Donnelly, J.P., Cleary, P., Newby, P., and Ettinger, R., 2004, Coupling instrumental and geological records of sea-level change: Evidence from southern New England of an increase in the rate of sea-level rise in the late $19^{\text {th }}$ century: Geophysical Research Letters, v. 31, L05203, doi: 10.1029/2003GL018933.

Friedrichs, C.T., and Perry, J.E., 2001, Tidal salt marsh morphodynamics: A synthesis: Journal of Coastal Research, v. 27, p. 7-37.

Gedan, K.B., Silliman, B.R., and Bertness, M.D., 2009, Centuries of human-driven change in salt marsh ecosystems: Annual Review of Materials Science, v. 1, p. 117-141, doi: 10.1146/ annurev.marine.010908.163930.

Gottschalk, L.C., 1945, Effects of soil erosion on navigation in Upper Chesapeake Bay: Geographical Review, v. 35, p. 219-238.

Hall, B., Motzkin, G., Foster, D.R., Syfert, M., and Burk, J., 2002, Three hundred years of forest and land-use change in Massachusetts, USA: Journal of Biogeography, v. 29, p. 1319-1335, doi: 10.1046/j.1365-2699.2002.00790.x.

Hopkinson, C.S., 2007, Dissolved nutrient and particulate concentrations of freshwater inputs to the Plum Island estuarine system, taken approximately monthly: Plum Island Ecosystem LTER Database: http://ecosystems.mbl.edu/ PIE/data/WAT/WAT-VA-Inputs.html.

Kearney, M.S., Rogers, A.S., Townsend, G., Rizzo, E., and Stutzer, D., 2002, Landsat imagery shows decline of coastal marshes in Chesapeake and Delaware Bays: Eos (Transactions, American Geophysical Union), v. 83, p. 173178, doi: 10.1029/2002EO000112.

Kirwan, M.L., and Murray, A.B., 2007, A coupled geomorphic and ecological model of tidal marsh evolution: National Academy of Sciences Proceedings, v. 104, p. 6118-6122, doi: 10.1073/pnas.0700958104.

Mattheus, C.R., Rodriguez, A.B., and McKee, B.A., 2009, Direct connectivity between upstream and downstream promotes rapid response of lower coastal-plain rivers to land-use change: Geophysical Research Letters, v. 36, L20401, doi: 10.1029/2009GL039995.

McCormick, C.L., 1968, Holocene stratigraphy of the marshes at Plum Island, Massachusetts [Ph.D. thesis]: Amherst, University of Massachusetts, $104 \mathrm{p}$.

McIntire, W.G., and Morgan, J.P., 1963, Recent geomorphic history of Plum Island, Massachusetts and Adjacent Coasts: Baton Rouge, Louisiana State University Press, 44 p.

Meade, R.H., and Trimble, S.W., 1974, Changes in sediment loads in rivers of the Atlantic drainage of the United States since 1900, in Rodda, J.C., eds., Effects of man on the interface of the hydrological cycle with the physical environment: Proceedings of the Paris symposium: In- ternational Association of Scientific Hydrology Publication 113, p. 99-104.

Parshall, T., Foster, D.R., Faison, E., Macdonald, D. and Hansen, B.C.S., 2003, Long-term history of vegetation and fire in pitch pine-oak forests on Cape Cod Massachusetts: Ecology, v. 84, p. 736-748, doi: 10.1890/0012-9658(2003)084 [0736:LTHOVA]2.0.CO;2.

Pasternack, G.B., Brush, G.S., and Hilgartner, W.B., 2001, Impact of historical land-use change on sediment delivery to a Chesapeake Bay subestuarine delta: Earth Surface Processes and Landforms, v. 26, p. 409-427, doi: 10.1002/esp.189.

Pavich, M.J., Brown, L., Valette-Silver, J.N., Klein, J., and Middleton, R., 1985, ${ }^{10} \mathrm{Be}$ analysis of a Quaternary weathering profile in the Virginia Piedmont: Geology, v. 13 , p. 39-41, doi: 10.1130 / 0091-7613(1985)13<39:BAOAQW>2.0.CO;2.

Rampino, M.R., and Sanders, J.E., 1981, Episodic growth of Holocene tidal marshes in the northeastern United States: A possible indicator of eustatic sea-level fluctuations: Geology, v. 9, p. 63-67, doi: 10.1130/0091-7613(1981)9<63: EGOHTM>2.0.CO;2.

Redfield, A.C., 1965, Ontogeny of a salt marsh estuary: Science, v. 147 , p. 50-55, doi: $10.1126 /$ science.147.3653.50.

Saenger, C., Cronin, T.M., Willard, D., Halka, J., and Kerhin, R., 2008, Increased terrestrial to ocean sediment and carbon fluxes in the northern Chesapeake Bay associated with twentieth century land alteration: Estuaries and Coasts, v. 31, p. 492-500, doi: 10.1007/s12237-008-9048-5.

Swales, A., and Bentley, S.J., 2008, Recent tidal-flat evolution and mangrove-habitat expansion: Application of radioisotope dating to environmental reconstruction, in Sediment dynamics in changing environments: International Association of Hydrological Sciences Publication 325, p. 76-84.

Syvitski, J.P.M., Vorosmarty, C.J., Kettner, A.J., and Green, P., 2005, Impact of humans on the flux of terrestrial sediment to the global coastal ocean: Science, v. 308, p. 376-380, doi: 10.1126/science. 1109454

Trimble, S., 1977, The fallacy of stream equilibrium in contemporary denudation studies: American Journal of Science, v. 277, p. 876-887, doi: 10.2475/ajs.277.7.876.

Walter, R.C., and Merritts, D.J., 2008, Natural streams and the legacy of water-powered mills: Science, v. 319, p. 299-304, doi: 10.1126/ science. 1151716.

Ward, L.G., Zaprowski, B.J., Trainer, K.D., and Davis, P.T., 2008, Stratigraphy, pollen history, and geochronology of tidal marshes in a Gulf of Maine estuarine system: Climatic and relative sea level impacts: Marine Geology, v. 256, p. 1-17, doi: 10.1016/j.margeo.2008.08.004.

Yang, S.L., Zhang, J., Zhu, J., Smith, J.P., Dai, S.B., Gao, A., and Li, P., 2005, Impacts of dams on Yangtze River sediment supply to the sea and delta intertidal wetland response: Journal of Geophysical Research, v. 110, F03006, doi: 10.1029/2004JF000271.

Zhou, H., Peng, X., and Pan, J., 2004, Distribution, source and enrichment of some chemical elements in sediments of the Pearl River Estuary, China: Continental Shelf Research, v. 24, p. 1857-1875, doi: 10.1016/j.csr.2004.06.012.

Manuscript received 28 September 2010

Revised manuscript received 12 January 2011

Manuscript accepted 16 January 2011

Printed in USA 